\title{
Nutrient cycling in ecological aquaculture wastewater treatment systems: vertical distribution of benthic phosphorus fractions due to bioturbation activity by Tegillarca granosa
}

\author{
Regan Nicholaus ${ }^{1}$, Betina Lukwambe ${ }^{1}$, Hang Lai ${ }^{1}$, Wen Yang ${ }^{1,2}$, \\ Zhongming Zheng ${ }^{1,2, *}$
}

\author{
${ }^{1}$ School of Marine Sciences, Ningbo University, Ningbo 315832, PR China \\ ${ }^{2}$ Collaborative Innovation Center for Zhejiang Marine High-efficiency and Healthy Aquaculture, Ningbo 315832, PR China
}

\begin{abstract}
Fractionation of sediment phosphorus (P) was conducted to examine the distribution and bioavailability of P fractions in a blood clam Tegillarca granosa-based ecological aquaculture wastewater treatment system. In a laboratory experiment, either a low or high density of clams, or no clams (control), were added to a polypropylene chamber containing aquaculture wastewater and an $8 \mathrm{~cm}$ sediment layer. Distribution and bioavailability of inorganic P (Inorg-P) - which included exchangeable $\mathrm{P}(\mathrm{Ex}-\mathrm{P})$, metal oxide-bound $\mathrm{P}(\mathrm{NaOH}-\mathrm{P})$, calcium-bound $\mathrm{P}$ (HCl-P), redoxsensitive $\mathrm{P}(\mathrm{BD}-\mathrm{P})$, and detrital $\mathrm{P}(\mathrm{De}-\mathrm{P})$ - and organic $\mathrm{P}$ (Org-P) in the sediment were investigated after $30 \mathrm{~d}$ using a sequential extraction procedure (SEDEX). Results showed that $T$. granosa bioturbation activities markedly changed the contents of $\mathrm{P}$ fractions, especially Ex-P, NaOH-P, BD-P, and Org-P ( $\mathrm{p}<0.05)$. Total Inorg-P varied from 1.83 to $6.75 \mu \mathrm{mol} \mathrm{g}^{-1}$, with an average of $4.29 \pm 1.37 \mu \mathrm{mol}$ $\mathrm{g}^{-1}$ among the 3 groups. Org-P ranged from 5.01 to $9.76 \mu \mathrm{mol} \mathrm{g}^{-1}$ and accounted for 22 to $41 \%$ of total $\mathrm{P}$ (TP). Despite some variation in contents at different depths, the average proportions of $\mathrm{P}$ fractions to TP were, in ascending order, Ex-P, BD-P, NaOH-P, HCl-P, De-P, and Org-P. Inorg-P had the highest proportions $(73.83 \%)$ of TP. Bioavailable P (Ex-P, NaOH-P, and BD-P) proportions were 61, 58.23 , and $44.44 \%$, respectively, relative to the control. The variant contents of the $\mathrm{P}$ fractions were most probably due to enhanced organic matter consumption and mineralization, metal oxide dissolutions, and the increased bioavailable $\mathrm{P}$ in the bioturbated sediment. This study suggests that T. granosa can modify the concentrations, distribution, and bioavailability of sedimentary P, as well as reduce Org-P. Our study further advances the knowledge on $\mathrm{P}$ cycling and provides theoretical assistance for monitoring $P$ in aquatic environments.
\end{abstract}

KEY WORDS: Phosphorus fractions - Sediments - Tegillarca granosa - Aquaculture wastewater · Bioavailable phosphorus

\section{INTRODUCTION}

Aquaculture is the agroindustrial activity with the highest growth rate worldwide. The production of aquaculture has an annual growth rate of $8 \%$ and contributes $44.1 \%$ of the world fish supply of 167.2 million metric tonnes (Mt) (FAO 2016). Hall et al.

${ }^{*}$ Corresponding author: zhengzhongming@nbu.edu.cn
(2011) estimated that aquaculture production will grow from $60 \mathrm{Mt}$ in 2010 to $100 \mathrm{Mt}$ by 2030 to meet the ever-increasing demand for fish food production. In aquaculture, similar to any other food production industry, inputs (e.g. chemicals, water, feeds, antibiotics) are necessary to generate the intended products. Because of the incomplete transformation of these in-

(C) The authors 2019. Open Access under Creative Commons by Attribution Licence. Use, distribution and reproduction are unrestricted. Authors and original publication must be credited. 
puts to final products, and poor management, aquaculture wastes are increasingly discharged into the surrounding environment (Crab et al. 2007, Cubillo et al. 2016). Wastes associated with high levels of nitrogen $(\mathrm{N})$ and phosphorus (P) can lead to critical environmental damage and irreversible ecosystem degradation. Previous research has found that about $67 \%$ of $\mathrm{P}$ applied to aquaculture facilities (e.g. ponds) as feed accumulates in sediments (Masuda \& Boyd 1994).

$\mathrm{P}$, while a common pollutant in aquaculture effluent waters, is one of the most essential and critically limited nutrients governing the growth of animals and plants (Shilla et al. 2009). It can be classified in various forms such as organic $\mathrm{P}$ (Org-P), exchangeable or loosely sorbed $\mathrm{P}$ (Ex-P), metal oxide-bound $\mathrm{P}$ (NaOH-P), calcium-bound $\mathrm{P}$ (HCl-P), redox-sensitive $\mathrm{P}$ (BD-P), and detrital P (De-P) (Wang et al. 2019). Variations in $\mathrm{P}$ fractions in the sediment dictate the $\mathrm{P}$ exchange between the sediment and overlying water, the water quality, and P bioavailability in the system (Zheng et al. 2004). The amount of P released from the sediment to the bottom water depends on the different chemical-physical conditions and the biological environment as well as the $P$ fractions (distribution and quantity) within the sediment (Zheng et al. 2004, Jin et al. 2006, Łukawska-Matuszewska \& Bolałek 2008, Shilla et al. 2009). Benthic P can best be estimated by determining total P (TP) and its individual $\mathrm{P}$ fractions separately, owing to its different chemical and biological properties in sediment (Ruttenberg 1992).

In most enclosed aquaculture ecosystems $\mathrm{P}$ is generated in part from the sediment (internal loading) and from anthropogenic activities (Kaiserli et al. 2002). The content of $P$ released and trapped by surface sediments greatly depends on the amount of organic particles available in the overlying water and the discharging systems. P produced from sediment degradation activities is carried in porewater and eventually released to the water column where it is easily accessible to plankton species (Zhang et al. 2008). Excess $P$ in the environment can affect primary productivity, resulting in eutrophication (e.g. Roy-Poirier et al. 2010) as well as changing the biogeochemical cycling of nutrients in the ecosystem (Meng et al. 2015, Wang et al. 2015, Bastami et al. 2018). In the long run, the $P$ content in aquatic systems becomes buried/accumulated in the sediments.

Sediments are actively involved in aquatic nutrient uptake and regeneration processes under different biological conditions (Reddy et al. 2005, Zhu et al. 2008) and contribute a paramount role in the cycling of $P$ (Wang et al. 2015). Sediment's ability to retain P depends on its physiochemical characteristics and the oxidation-reduction conditions at the sedimentwater interface (SWI) (Bostic \& White 2007). Reservoirs, estuaries, and earthen aquaculture pond bottoms can play an important role as a source or sink of sedimentary P (Wang et al. 2017). Deposition of sediment $\mathrm{P}$ can occur through assimilation in calcium carbonate minerals and/or organic matter (OM) mineralization (Jin et al. 2006, Ribeiro et al. 2008, Küster-Heins et al. 2010), which can be affected by environmental conditions (Huo et al. 2011) and bioturbating organisms such as Venus clam and blood clam Tegillarca granosa.

T. granosa is a shallow-burrowing benthic filterfeeding marine bivalve which naturally lives and is usually cultivated on mud in the intertidal zone with a water salinity of around 10-32 ppt (Kuang \& Sun 1995) and optimum temperature ranging from 20 to $30^{\circ} \mathrm{C}$. This species is mostly found distributed throughout the Indo-Pacific region, including South Africa, Australia, Polynesia, Japan, and China (Nguyen et al. 2017). It has a high economic value as food, and is cultivated aquaculturally. Globally, the production of $T$. granosa increased from 31298 to 66195 metric tons (t) from 2007 to 2016 (FAO 2016). For China, Taiwan, and South Korea, the FAO Yearbook of Fishery Statistics reports that yearly capture production of this species rose from around $1415 \mathrm{t}$ in 1995 to $6503 \mathrm{t}$ in 1999. The coast of Zhejiang Province, China, is among the largest producers of blood clam, occupying $\sim 100 \mathrm{~km}^{2}$ of mudflats production area. The Guangdong and Fujian coastal regions are popular for field farming, with each production area covering up to 50-60 ha (Mao et al. 2019).

The feeding habit of $T$. granosa is related to the bottom feeds where it lives, and includes organic detritus (98\%), phytoplankton, and unicellular algae (Phuc 1997). T. granosa has 2 equal shells held together with a ligament and opened and closed with muscles, and strong, burrowing feet that it uses to bury itself in the sand. It can burrow between 1 and $4 \mathrm{~cm}$ down the sediment (Nicholaus et al. 2019). Like other clams, T. granosa draws in water and filters out organic detritus/phytoplankton for feeding (Phuc 1997, Ramli \& Abu Hasan 2013). During sediment reworking in a process known as bioturbation, $T$. granosa can potentially influence the cycling and distribution of benthic biogeochemical nutrients and remediate aquaculture wastewater (Nicholaus et al. 2019). Bioturbation by invertebrate species affects the internal loading 
and cycling process of $\mathrm{P}$ in an aquatic ecosystem (Kaiser et al. 2002). Accordingly, bioturbation activities can directly or indirectly affect a number of processes, such as redox potential, acid-base property, dissolved oxygen (DO), OM, microbial community, and iron-aluminum oxides/hydroxides that are thought to primarily control the distribution of $\mathrm{P}$ fractions (Li et al. 2016).

Various studies on the distribution of sedimentary $P$ fractions in both marine and freshwater sediments have been performed (e.g. Huo et al. 2011, Meng et al. 2014, Yang et al. 2016, 2018, Cao et al. 2019); however, understanding the vertical distribution of benthic $P$ fractions in aquaculture wastewater treatment systems is important for improving the nutrient cycling and optimization of the system. This study aimed to quantify the contents of the major $\mathrm{P}$ fractions in clam-bioturbated pond sediment and to investigate the influence of $T$. granosa's ecological activity on the distribution and bioavailability of $P$ fractions in an ecological aquaculture wastewater treatment system. Studying bivalve bioturbation impacts on the distribution and speciation of $\mathrm{P}$ fractions may further improve the understanding of the mechanisms of aquaculture wastewater treatment systems.

\section{MATERIALS AND METHODS}

\subsection{Bivalve, aquaculture wastewater, and sediment collection}

Aquaculture wastewater and sediment were collected from the Ningbo Shrimp Production Center in Ningbo, Zhejiang Province, China. For consistency, reliability, and homogeneity, the experimental sediments were thoroughly homogenized by stirring and sieving to remove large particles and macrofauna before being distributed into the respective experimental chambers (Wang et al. 2015, Hou et al. 2018). The sediment was passed through a $1 \mathrm{~mm}$ mesh diameter sieve to remove large particles/macrobenthos. The freshly collected sediment had a porosity of $51.8 \%$ and OM content of $7.9 \%$, and it was comprised of $31 \%$ sand and $66 \%$ silt and clay. Locally farmed blood clams Tegillarca granosa (average biovolume $\pm \mathrm{SD}, 4.92 \pm 0.43 \mathrm{~g} \mathrm{ml}^{-1}$ ) were collected from a local commercial farm. The clams were acclimatized for $15 \mathrm{~d}$ prior to the experiment. Throughout the study, the clams fed on the naturally existing organic detritus/phytoplankton/algae from the aquaculture wastewater.

\subsection{Experimental design}

A laboratory experiment was carried out for $30 \mathrm{~d}$ in an artificially constructed mesocosm system designed with a plastic bucket $\left(0.55 \mathrm{~m}^{3}\right)$ filled with approximately $480 \mathrm{l}$ of aquaculture wastewater and 12 small polypropylene $(\mathrm{PP})$ chambers $(0.125 \times 0.125 \times$ $0.25 \mathrm{~m}=0.00391 \mathrm{~m}^{3}$ ). An $8 \mathrm{~cm}$ thick layer of wellsieved sediment was spread on the bottom of each PP chamber, and all chambers were filled with aquaculture wastewater. The experiment consisted of 3 treatments: control (no clams), low density (1 clam chamber $^{-1}$ ), and high density (4 clams chamber ${ }^{-1}$ ). The treatment densities were set according to the optimal stocking densities equivalent to 63-252 clams $\mathrm{m}^{-2}$. Each treatment group consisted of 4 replicates. With the lids removed, the chambers (with sediment + clams + aquaculture wastewater) were carefully lowered down into the mesocosm. Aeration was provided every other day, during which approximately $50 \%$ of the water in the mesocosm was replaced with fresh aquaculture wastewater. Water temperature was maintained at $23 \pm 0.5^{\circ} \mathrm{C}$, and salinity ranged from 26 to 29 PSU.

\subsection{Post-treatment sampling}

Sampling of sediment and water for measurements of $\mathrm{P}$ fractions and overlying-water $\mathrm{P}$ (OWP) occurred at the end of the experiment (Day 30). All experimental chambers were carefully taken out and $\sim 20 \mathrm{ml}$ of overlying water (for phosphate analysis) was collected by gently siphoning with rubber tubing $1 \mathrm{~cm}$ above the sediment surface. Then the entire remaining overlying water was gently siphoned out of each chamber. The sediment core in each chamber was sliced into 3 sections at different intervals to create 3 sampling areas: (1) surface $(0-2 \mathrm{~cm}),(2)$ middle $(2-$ $4 \mathrm{~cm}$ ), and (3) bottom $(4-8 \mathrm{~cm})$, for sediment $P$ fractions, OM, and total N (TN) analysis. Sediment samples were collected using a $30 \mathrm{~cm}$ long Plexiglas, and all subsamples were immediately placed in sterile and sealable plastic bags with air excluded before storage at $-20^{\circ} \mathrm{C}$ for later analyses.

\subsection{Laboratory analysis}

Sequential extraction and measurement of $P$ fractions. To extract the $\mathrm{P}$ fractions, a sequential extraction was performed in triplicate with $0.5 \mathrm{~g}$ freezedried sediment samples in $50 \mathrm{ml}$ centrifuge tubes 
using a sequential extraction method (SEDEX) modified from Ruttenberg (1992) and Yang et al. (2016) (Fig. 1). This method analyzes the most commonly known sedimental $\mathrm{P}$ fractions: Ex-P, NaOH-P, HCl$\mathrm{P}, \mathrm{BD}-\mathrm{P}, \mathrm{De}-\mathrm{P}$, and Org-P. During the extraction process, modifications were made following Yang et al. (2016) to reduce interference from the citratedithionite-bicarbonate (CDB) reagent with the SEDEX process. Fig. 1 shows the detailed extraction process of all the extracted $\mathrm{P}$ species. The concentration of Org-P was measured as the difference between $1 \mathrm{M} \mathrm{HCl}$ extractable P (24 h) before and after high-temperature combustion $\left(550^{\circ} \mathrm{C}, 2 \mathrm{~h}\right)$ of the sediment. Inorganic $\mathrm{P}$ (Inorg-P) was the sum of the 5 $\mathrm{P}$ forms Ex-P, BD-P, NaOH-P, HCl-P, and De-P after extraction by the SEDEX method. TP was calculated as the sum of Inorg-P and Org-P (Slomp et al. 1996). To avoid underestimation of Org-P concentration (Ruttenberg 1992), a separate extraction procedure was applied (Yang et al. 2016). In addition, other vital conditions for the extracts were maintained (Zhang et al. 2010, Lin et al. 2013), and all samples were analyzed in triplicate after filtration (GF/F, Whatman, $0.45 \mu \mathrm{m})$. The OWP and all $\mathrm{P}$ fraction extracts (supernatants) were analyzed by the ascorbic acid-phosphomolybdate blue method (Wang et al. 2005) using a WESTCO SmartChem discrete analyzer.

Sediment total organic matter (OM). The OM contents of the sediment samples were determined by igniting a dry $0.2 \mathrm{~g}$ sediment sample for $4 \mathrm{~h}$ at $550^{\circ} \mathrm{C}$ (mass loss on ignition, LOI; White \& Reddy 1999).

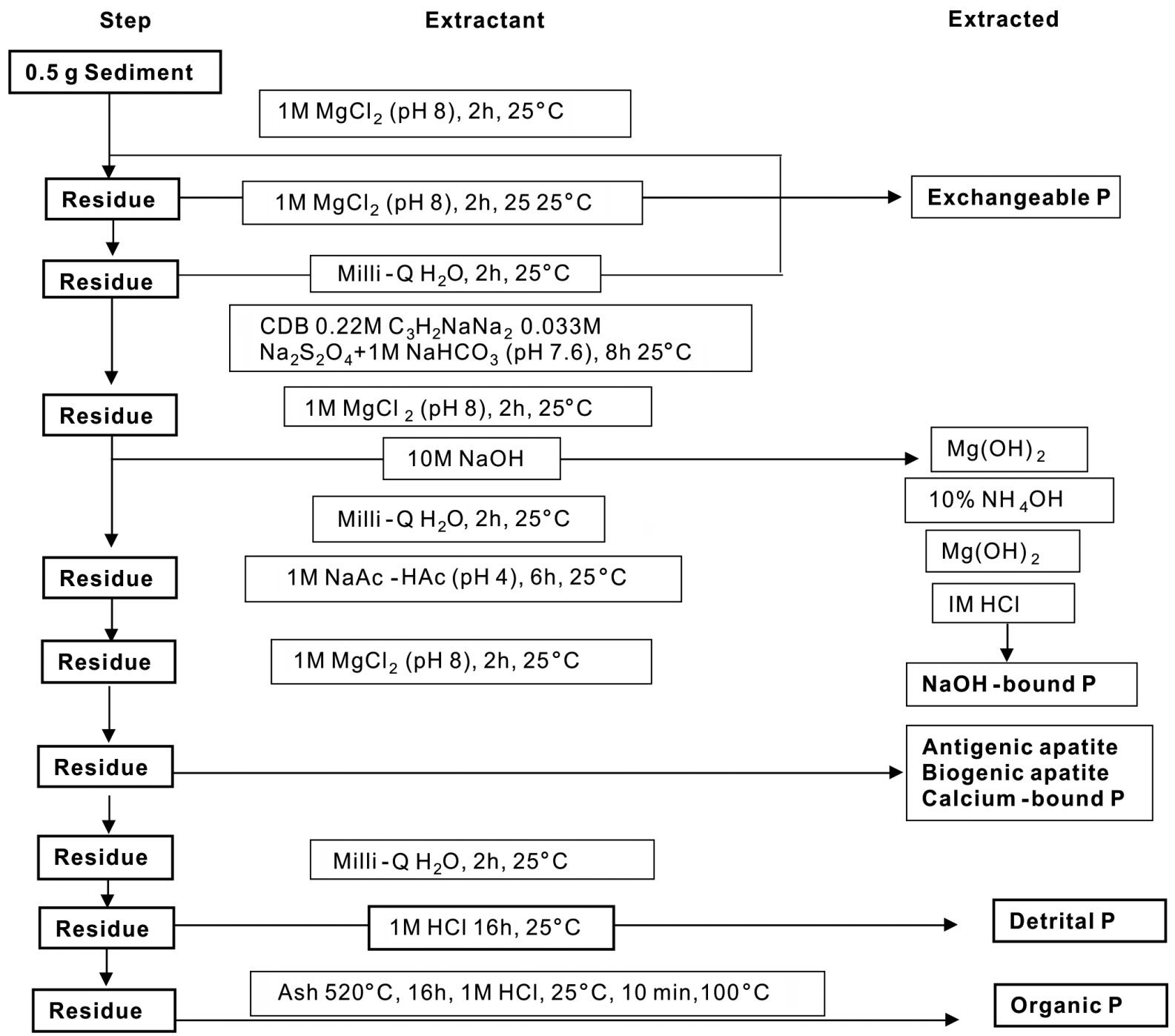

Fig. 1. Phosphorus (P) fractions extraction procedure (SEDEX) for aquatic surface sediments, modified from Ruttenberg (1992) and Yang et al. (2016) 


\subsection{Statistical data analysis}

P fraction concentrations were analyzed using a multivariate analysis of variance (MANOVA) and a 1-way ANOVA in SPSS 16.0, with density, time, and depth as independent factors. Tukey's post hoc test was conducted to identify statistically significant data groups. The normality and homoscedasticity of data were tested prior to each statistical analysis. Pearson correlation analysis was used to identify relationships between $\mathrm{P}$ fractions and other diverse physicochemical parameters. For all statistical tests, results were considered significant at $p<0.05$. Figures were drawn with the Origin Pro 8.0 scientific graphing and data analysis software.

\section{RESULTS}

\subsection{Vertical distribution of benthic $P$ fractions}

The concentrations of $\mathrm{P}$ fractions in the freshly sieved sediments were: 2.6 , $2.9,5,6.7,11.03,13.94$, and $36.81 \mu \mathrm{mol}$ $\mathrm{g}^{-1}$ for BD-P, Ex-P, NaOH-P, HCl-P, De- $\mathrm{P}$, Org- $\mathrm{P}$, and $\mathrm{TP}$, respectively. The concentrations and percentage contributions for the different $\mathrm{P}$ fractions in the treatments are shown in Fig. 2 and Table 1. TP in the bioturbated sediment (i.e. the low-density and highdensity treatments) ranged from 13.75 \pm 5.78 to $31.72 \pm 7.46 \mu \mathrm{mol} \mathrm{g}^{-1}$, with an average of $22.73 \pm 6.62 \mu \mathrm{mol} \mathrm{g}{ }^{-1}$ (Fig. 2), suggesting a decrease of the sedimentary TP. Ex-P in bioturbated sediments displayed significantly higher concentrations between layers in each treatment, particularly in the surface (ANOVA, $F_{2,18}=1.841, p=0.043$ ) and the middle layer $\left(F_{2,18}=1.328, \mathrm{p}=0.019\right)$ (Fig. 2A). The mean concentration of Ex-P in the entire $8 \mathrm{~cm}$ sediment profile of the control, lowdensity, and high-density treatments was $2.06 \pm$ $0.4,2.82 \pm 0.1$, and $4.2 \pm 1.7 \mu \mathrm{mol} \mathrm{g}^{-1}$, respectively (Fig. 2A). NaOH-P contents (average $\pm \mathrm{SD}$ ) in the clam-bioturbated chambers varied between $1.51 \pm$ $0.4 \mu \mathrm{mol} \mathrm{g}^{-1}$ (low-density) and $4.85 \pm 0.3 \mu \mathrm{mol} \mathrm{g}^{-1}$
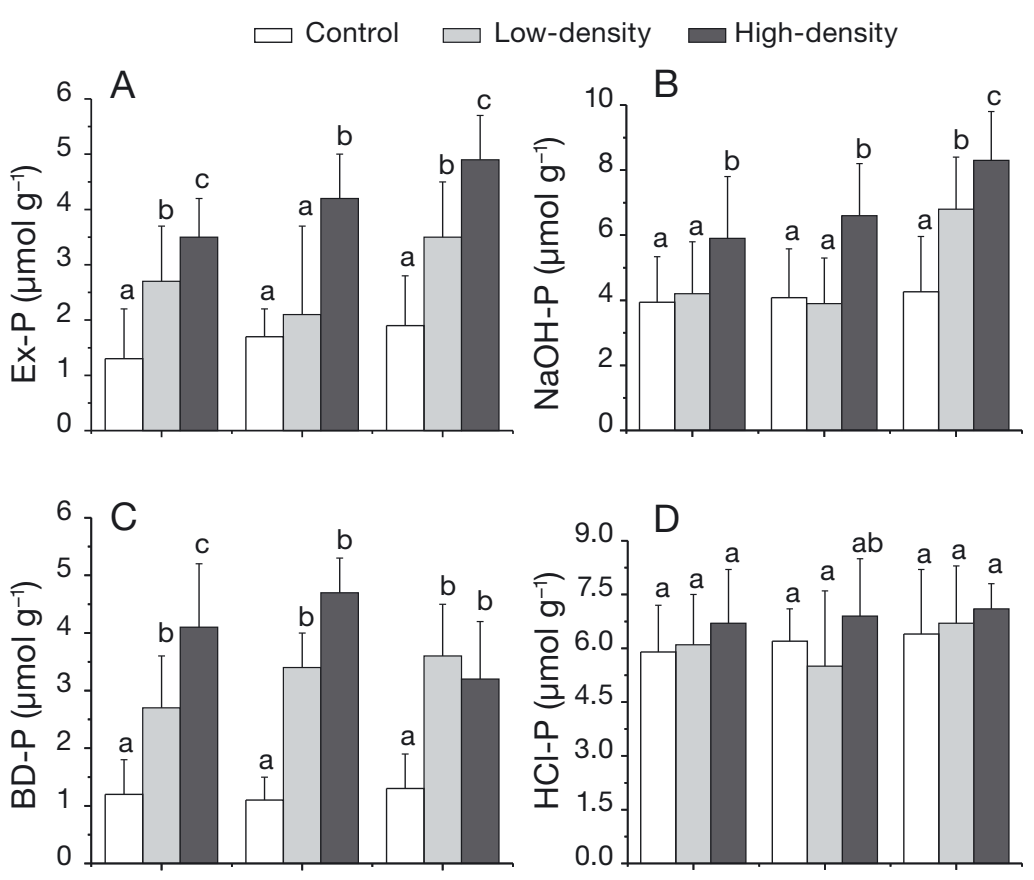

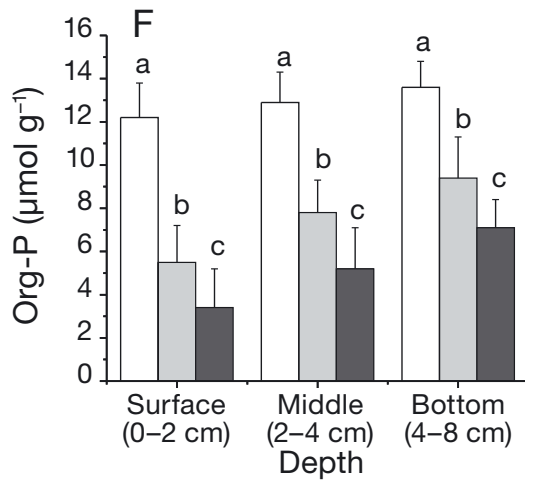

Fig. 2. Phosphorus $(\mathrm{P})$ concentrations (mean $\pm \mathrm{SD} ; \mathrm{n}=4$ ) of the vertical distributions of different $P$ fractions: (A) exchangeable or loosely sorbed P (Ex-P), (B) metal oxide-bound $\mathrm{P}(\mathrm{NaOH}-\mathrm{P}),(\mathrm{C})$ redox-sensitive $\mathrm{P}$ (BD-P), (D) calciumbound $\mathrm{P}(\mathrm{HCl}-\mathrm{P})$, (E) detrital $\mathrm{P}(\mathrm{De}-\mathrm{P})$, and $(\mathrm{F})$ organic $\mathrm{P}(\mathrm{Org}-\mathrm{P})$, measured in the $0-8 \mathrm{~cm}$ sediment profile in the Tegillarca granosa treatments. Letters denote significant differences $(\mathrm{p}<0.05)$ within the same treatment

Table 1. Contribution of each phosphorus (P) fraction to sediment total $\mathrm{P}$ in the Tegillarca granosa treatments. BD-P: redox-sensitive $\mathrm{P}_{\text {; }}$ De-P: detrital $\mathrm{P}$; Ex-P: exchangeable or loosely sorbed $\mathrm{P}_{;}$ HCl-P: calcium-bound $\mathrm{P}$; NaOH-P: metal oxide-bound $\mathrm{P}$; Org-P: organic $\mathrm{P}$

\begin{tabular}{|lccccccc|}
\hline \multirow{2}{*}{ Treatment } & \multicolumn{7}{c|}{ Contribution (\%) } \\
\cline { 2 - 7 } & Ex-P & BD-P & NaOH-P & HCl-P & De-P & Org-P \\
\hline Control & 8.6 & 10 & 7.1 & 17 & 13 & 44.3 \\
Low-density & 12.3 & 13 & 15 & 14 & 8.6 & 37.1 \\
High-density & 15.9 & 18 & 17 & 17 & 11 & 26.1 \\
\hline
\end{tabular}


(high-density) (Fig. 2B). The amount of $\mathrm{NaOH}-\mathrm{P}$ was significantly increased among the treatments, by $17.1 \%$ (high-density) and 15\% (low-density) compared to the control.

Both low- and high-density treatments showed significantly increased amounts of sedimentary BD-P than the control (Tukey's HSD, p < 0.05; Fig. 2C). BD-P concentrations were 1.1 to $1.3 \mu \mathrm{mol} \mathrm{g}{ }^{-1}(1.25 \pm$ $0.5 \mu \mathrm{mol} \mathrm{g}{ }^{-1}$ ), 2.7 to $3.6 \mu \mathrm{mol} \mathrm{g}^{-1}$ (3.15 $\pm 0.65 \mu \mathrm{mol}$ $\left.\mathrm{g}^{-1}\right)$, and 3.2 to $4.1 \mu \mathrm{mol} \mathrm{g}{ }^{-1}\left(3.65 \pm 0.7 \mu \mathrm{mol} \mathrm{g}{ }^{-1}\right)$ for the control, low-density, and high-density treatments, respectively. The concentration of Org-P was decreased greatly between the bioturbated and the control sediment at all depths (ANOVA, Tukey's HSD, p < 0.05; Fig. 2F); Org-P was decreased by $19 \%$ (low-density) and $37 \%$ (high-density) compared to the control. The concentration of TP decreased sharply in the high-density clam treatment group, especially in the 0-2 cm sediment layer (ANOVA, $F_{2,18}$ $=13.017, \mathrm{p}=0.0038)$ compared to the deeper $(4-8 \mathrm{~cm})$ sediments (ANOVA, $F_{2,18}=7.695, \mathrm{p}=0.044$; Fig. 3).

In regard to De-P, significant differences were observed at the surface sediment $(0-2 \mathrm{~cm})$ of both clam treatments (Fig. 2E), whereas none were recorded in the deeper layers $(2-8 \mathrm{~cm}$ depth). HCl-P was the least affected fraction, with non-significant variation (ANOVA, $F_{2,18}=3.091, \mathrm{p}>0.05$ ) among all treatment groups. However, $\mathrm{HCl}-\mathrm{P}$ displayed minor variation with an increasing trend from the control, low-density, to high-density treatments across the $0-8 \mathrm{~cm}$ depths (Fig. 2D). Generally, the bioavailable P (Ex-P, $\mathrm{NaOH}-\mathrm{P}, \mathrm{HCl}-\mathrm{P}$, and BD-P) increased among the bio-

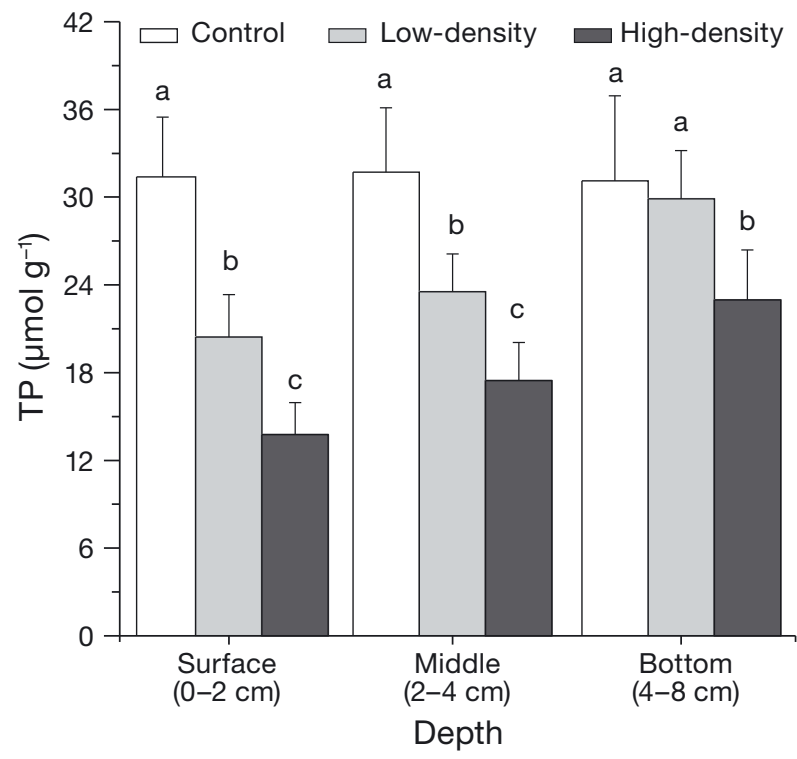

Fig. 3. Concentration (mean $\pm \mathrm{SD} ; \mathrm{n}=4$ ) of vertical total phosphorus (TP) in the 3 sediment layers for each Tegillarca granosa treatment group. Letters denote significant differences $(p<0.05)$ within the same treatment

turbated sediments (Fig. 4), with order rank: Ex-P > $\mathrm{NaOH}-\mathrm{P}>\mathrm{BD}-\mathrm{P}>\mathrm{HCl}-\mathrm{P}$, suggesting that the distributions and availability of the $\mathrm{P}$ fractions were related to the clam bioturbation activities.

The overall descending order of $\mathrm{P}$ species contribution to sediment TP was: Org- $\mathrm{P}, \mathrm{De}-\mathrm{P}, \mathrm{HCl}-\mathrm{P}, \mathrm{NaOH}-$ $\mathrm{P}, \mathrm{BD}-\mathrm{P}$, and Ex-P for control; Org-P, Ex-P, NaOH-P, De-P, BD-P, and HCl-P for low-density; and Org-P, Ex-P, NaOH-P, De-P, BD-P, and HCl-P for high-density treatments (Figs. $2 \& 4$, Tables 1-3).

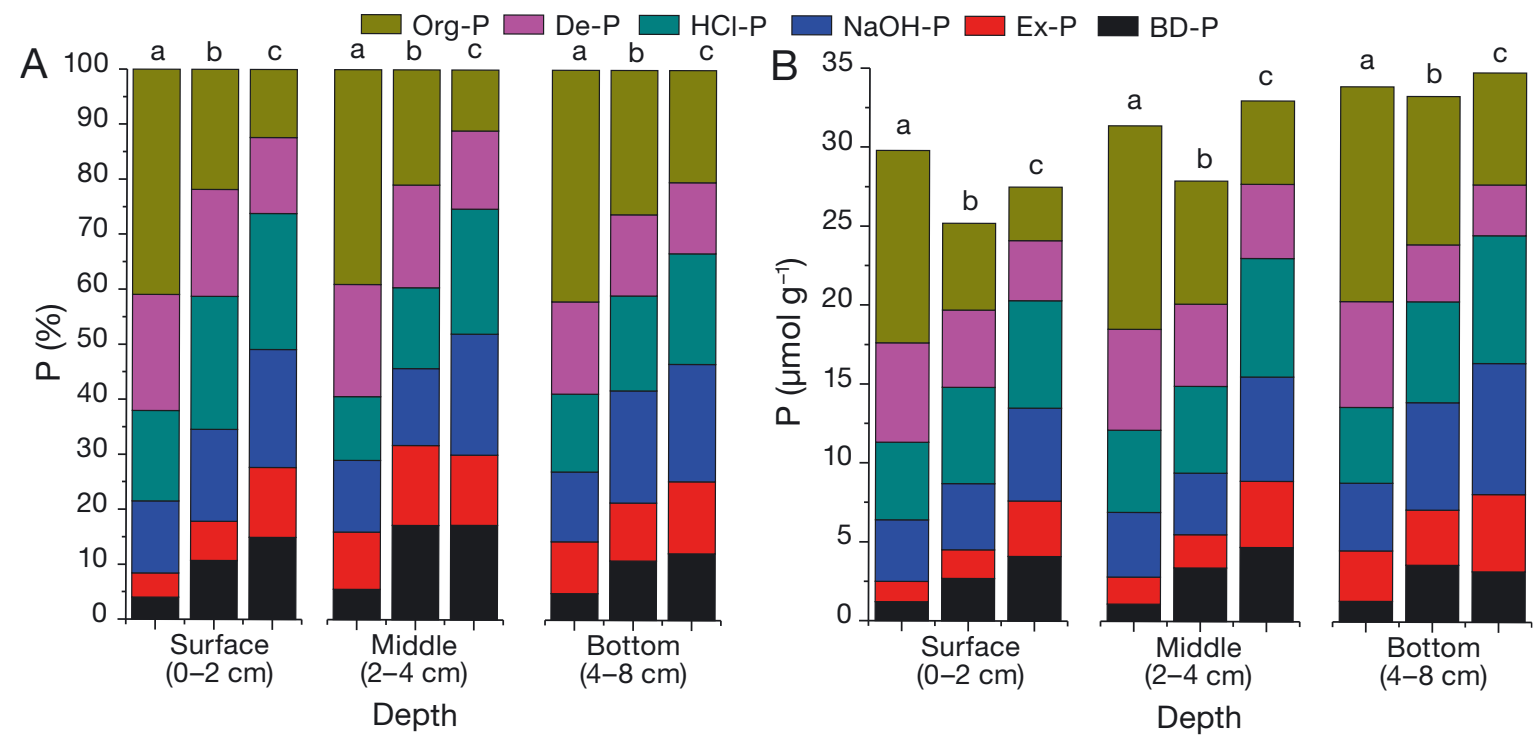

Fig. 4. (A) Relative proportions and (B) absolute concentrations of sedimentary phosphorus (P) fractions in the 3 sediment layers in the experimental groups: (a) control, (b) low density, and (c) high density of Tegillarca granosa. BD-P: redox-sensitive P; DeP: detrital P; Ex-P: exchangeable or loosely sorbed P; HCl-P: calcium-bound P; NaOH-P: metal oxide-bound P; Org-P: organic P 


\section{2. $P$ fraction contributions to TP}

The sediments from the blood clam treatments showed lower contributions of the Org-P fraction to sediment TP, and slightly higher for BD-P, NaOH-P, and De-P, compared to the non-bioturbated sediments (control), suggesting a decrease of organic wastes and increased level of bioavailable P. The contribution of each treatment group's NaOH-P concentration to each group's TP showed a stronger direct relationship with increasing bioturbation activities on the sediments; the higher the density of the clams, the higher the NaOH-P concentration in the sediment (Table 3). In the control sediment, Ex-P contributed the least $(8.6 \%)$ to $\mathrm{TP}$, whereas in the low- and high-clam density treatments, Ex-P contributed about 12.3 and $15.9 \%$ to TP respectively

Table 2. Concentrations of sediment total inorganic phosphorus (Total Inorg-P) and total organic phosphorus (Total OrgP) in the 3 sediment layers and of overlying-water phosphate (OWP) in the Tegillarca granosa treatments

\begin{tabular}{|c|c|c|c|c|}
\hline Phosphorus & $\begin{array}{l}\text { Depth } \\
\text { (cm) }\end{array}$ & Control & $\begin{array}{l}\text { Low- } \\
\text { density }\end{array}$ & $\begin{array}{l}\text { High- } \\
\text { density }\end{array}$ \\
\hline $\begin{array}{l}\text { Total Inorg-P } \\
\left.(\mu \mathrm{mol} \mathrm{g})^{-1}\right)\end{array}$ & $\begin{array}{l}0-2 \\
2-4 \\
4-8\end{array}$ & $\begin{array}{l}3.23 \\
3.78 \\
3.56\end{array}$ & $\begin{array}{l}5.94 \\
5.41 \\
4.78\end{array}$ & $\begin{array}{l}8.82 \\
7.53 \\
5.92\end{array}$ \\
\hline $\begin{array}{c}\text { Total Org-P } \\
\left(\mu \mathrm{mol} \mathrm{g}{ }^{-1}\right)\end{array}$ & $\begin{array}{l}0-2 \\
2-4 \\
4-8\end{array}$ & $\begin{array}{l}11.30 \\
12.42 \\
10.02\end{array}$ & $\begin{array}{l}5.42 \\
7.16 \\
9.34\end{array}$ & $\begin{array}{l}3.58 \\
5.35 \\
7.01\end{array}$ \\
\hline $\begin{array}{l}\text { OWP }\left(\mu \mathrm{mol} \mathrm{l}{ }^{-1}\right) \\
\text { aFor OWP, a wa } \\
\text { sediment surfa }\end{array}$ & $\begin{array}{l}1^{\mathrm{a}} \\
\mathrm{r} \text { sam }\end{array}$ & $\begin{array}{r}11.7 \\
\text { was co }\end{array}$ & $\begin{array}{l}19.02 \\
\text { d } 1 \mathrm{~cm}\end{array}$ & $\begin{array}{l}26.84 \\
\text { ove the }\end{array}$ \\
\hline
\end{tabular}

Table 3. Pearson correlation coefficients between the concentrations of different phosphorus (P) fractions, overlying-water phosphate (OWP), organic matter (OM), and total nitrogen (TN). BD-P: redox-sensitive P; De-P: detrital P; Ex-P: exchangeable or loosely sorbed $\mathrm{P}$; HCl-P: calcium-bound $\mathrm{P}$; NaOH-P: metal oxide-bound $\mathrm{P}$; Org-P: organic $\mathrm{P}$; TP: total P. ${ }^{*} \mathrm{p}<0.05$, ${ }^{* *} \mathrm{p}<0.01$

\begin{tabular}{|lccccccc|}
\hline & Ex-P & BD-P & NaOH-P & HCl-P & Org-P & De-P & TP \\
\hline Ex-P & & & & & & & \\
BD-P & 0.414 & & & & & & \\
NaOH-P & 0.137 & 0.131 & & & & & \\
HCl-P & -0.196 & 0.024 & -0.345 & & & & \\
Org-P & $0.952^{* *}$ & $0.795^{*}$ & 0.169 & $-0.847^{*}$ & & & \\
De-P & 0.262 & 0.371 & 0.058 & -0.284 & 0.503 & & \\
TP & $0.779^{* *}$ & -0.346 & $0.875^{* *}$ & 0.439 & $0.983^{* *}$ & 0.187 & \\
OWP & $0.796^{* *}$ & $0.585^{*}$ & $0.898^{*}$ & 0.035 & $0.894^{* *}$ & 0.192 & $0.952^{* *}$ \\
OM & $0.881^{* *}$ & $0.763^{*}$ & $0.817^{* *}$ & 0.367 & $0.899^{*}$ & 0.521 & $0.938^{* *}$ \\
TN & $0.567^{* *}$ & 0.135 & $0.774^{* *}$ & -0.308 & $0.412^{*}$ & $0.687^{*}$ & $0.592^{* *}$ \\
\hline
\end{tabular}

(Fig. 4, Table 1). Sediment from the high-density group had the highest $\mathrm{NaOH}-\mathrm{P}$ concentration, which contributed about $17.1 \%$ to sediment TP. Inorg-P in the bioturbated sediments dominated the Org-P, constituting between 62.9 and $73.9 \%(68.4 \% \pm 11.28 \%)$ of the TP (Fig. 4, Table 1).

\subsection{Pearson correlations}

Generally, the sediments exposed to bioturbation by blood clams showed increased amounts of total Inorg-P and reduced contents of total Org-P than the control sediments (Tables $1 \& 2$ ). High-density chambers had significantly higher concentrations of dissolved OWP compared to both control and low-density chambers (ANOVA, $\mathrm{p}<0.05$; Table 2 ). TP was significantly positively correlated with some of the $\mathrm{P}$ fractions (Ex-P, $r=0.779, p<0.01 ; \mathrm{NaOH}-\mathrm{P}, \mathrm{r}=0.875$, $\mathrm{p}<0.01)$, as was Org-P with Ex-P $(\mathrm{r}=0.952, \mathrm{p}<0.01)$ (Table 3). In addition, NaOH-P, Ex-P, Org-P, and TP were positively correlated with OWP $(\mathrm{r}=0.857, \mathrm{p}<$ 0.01 ; Table 2), which indicates that the amount of OWP was greatly dependent on the bioavailable P in the sediment.

\section{DISCUSSION}

Bivalve mollusks (e.g. clams, oysters, mussels, scallops) can play a role in engineering aquatic environmental stewardship and sustainability by promoting a healthy sedimental aquatic environment. For instance, bioturbating clams (e.g. blood clam Tegillarca granosa, Venus clam, razor clam) can remove $\mathrm{N}$ and $\mathrm{P}$ accumulated in the sediment and water as they rework the sediment through feeding and burrowing activities (Newell 2004, Lukwambe et al. 2018, Nicholaus et al. 2019, Zhao et al. 2019).

In this study, T. granosa significantly influenced the contents, distribution, and bioavailable $\mathrm{P}$ fractions within the sediments and the amounts of $\mathrm{P}$ in the overlying water (Figs. $2 \& 4$, Table 2). This may imply that variations in the contents of $\mathrm{P}$ fractions in the surface sediment $(0-8 \mathrm{~cm}$ depth, treatment groups) are attributable to the different amount of $\mathrm{OM}$ mineralized and decomposed by the clam's bioturbation and its synergic chemical activi- 
ties such as redox reactions (Hou et al. 2018). Sedimental deposited $\mathrm{P}$ can be altered and returned to the water column through various biological and physical activities such as OM, temperature, $\mathrm{pH}$, redox fluctuations, and bioturbations (Jin et al. 2006, Chen et al. 2011). Thus, in the sediment, the extent of $\mathrm{P}$ adsorption by $\mathrm{OM}$ is dependent on the quantity and quality of the OM present (Wang et al. 2006). The decomposition of OM releases phosphate ions, which adsorb to the surface of Fe oxides/hydroxides and clay soils, which are the major carriers of Ex-P in sediments (Andrieux-Loyer \& Aminot 2001, Yang et al. 2016).

Ex-P is the loosely absorbed, labile, and exchangeable $\mathrm{P}$ that comprises porewater $\mathrm{P}$ (Kaiserli et al. 2002). Various factors including water dynamics and redox potential can promote the Ex-P (Chen et al. 2011) in the sedimentary aquatic ecosystem. Ex-P was one of the most significantly increased $\mathrm{P}$ fractions (clam-treated chambers) and accounted for $15.9 \%$ (high-density treatment) and $12.3 \%$ (low-density treatment) of the TP compared to the control $(8.6 \%)$ (Table 1). This can be related to the bioturbation behavior of the clam to enhance transportation of oxygen, water irrigation, and OM mineralization in the sediment (Kaiserli et al. 2002, Søndergaard et al. 2003, Biswas et al. 2009). The clam's capacity to enhance sediment oxygen consumption (SOC) can also be supported by our recent study that investigated SOC specifically by T. granosa (Table 4 in the present study; Nicholaus et al. 2019). The enhanced redox conditions due to increased $\mathrm{O}_{2}$ supply within the sediment can largely affect the distribution of ExP (Łukawska-Matuszewska \& Bolałek 2008). Similarly, reduced OM particle size is among the influential factors controlling the contents and availability of Ex-P in sediments (Yang et al. 2016) due to an increased surface area and more binding sites of adsorbed P (Meng et al. 2015, Yang et al. 2019). The bioturbation of clams in the PP chamber might have increased the surface area and resuspension, and re-

Table 4. Evidence from the literature for sediment oxygen consumption by bivalve clams (including Tegillarca granosa) in aquatic sediments

\begin{tabular}{|lcl|}
\hline Clam species & $\begin{array}{c}\text { Consumption rate } \\
\left(\mathrm{mmol} \mathrm{O}_{2} \mathrm{~m}^{-2} \mathrm{~h}^{-1}\right)\end{array}$ & Reference \\
\hline T. granosa & $1.26-5.87$ & Nicholaus et al. (2019) \\
Cyclina sinensis & $4-8.5$ & Nicholaus \& Zheng (2014) \\
Sinonovacula constricta & $1.73-3.30$ & Zhao et al. (2019) \\
Macoma (Limecola) baltica & 1417 & Karlson et al. (2005) \\
Corbicula fluminea & $2500-3000$ & Zhang et al. (2011) \\
\hline
\end{tabular}

duced the grain size of sediment, resulting in a higher adsorption rate of Ex-P. However, the mineralization process by the clam during OM decomposition can increase the escape of sedimentary Ex-P into the water column, increasing the phosphate flux across the SWI (Nicholaus \& Zheng 2014), leading to effluent reduction.

Inorg-P species such as NaOH-P represent watersoluble and biologically available $\mathrm{P}$ which is usually easily available to algae and mostly responsible for promoting eutrophication in water bodies (Zhou et al. 2001, Ribeiro et al. 2008). Proportionally, NaOH-P showed higher concentrations in the sediments bioturbated by the clams. The significant increase of $\mathrm{NaOH}-\mathrm{P}$ relative to the control can be related to the resultant activities of $T$. granosa bioturbation processes such as improved oxygenation in the sediment (Nicholaus et al. 2019, Zhao et al. 2019; Table 4 in the present study). Due to the strong chemical relationship between $\mathrm{O}_{2}$, ferrous (FeII) and ferric (FeIII) oxides, $\mathrm{Fe}(\mathrm{OOH})-\mathrm{P}$, and goethite and hematite (Zak \& Gelbrecht 2002), more P adsorption processes likely took place as a result of a stimulated redox reaction (Bastami et al. 2018).

$\mathrm{NaOH}-\mathrm{P}$ fractions are controlled by the chemical reaction of $\mathrm{Fe}$ and $\mathrm{Al}$ occurring at the sediment surface (Huo et al. 2011). High oxygen supply may increase the availability of electron acceptors, hence promoting the formation of Fe(III)-P. However, when conditions turn anoxic, ferric oxides are reduced to ferrous oxides and some $\mathrm{P}$ ions can be released to overlying water (Bastami et al. 2018, Hou et al. 2018). Adsorption of $\mathrm{P}$ from the clay part and $\mathrm{Fe} / \mathrm{Al}$ (hydr)oxides is based on ligand exchange, whereby [OH-] substitutes P. This implies that the bioirrigation activities of clams may affect $\mathrm{pH}$ and can result in the subsequent increase of the negatively charged absorbing oxides. This suggests that the increased amounts of $\mathrm{NaOH}-\mathrm{P}$ among the treatments were due to unstable equilibrium between the P sorption (binding) and desorption (release) rate which was probably enhanced by the presence of clam disturbances. Our results of $\mathrm{NaOH}-$ $\mathrm{P}$ are in congruence with Zhang et al. (2011), who reported that bioturbation by the clam Corbicula fluminea increased the $\mathrm{NaOH}-\mathrm{P}$ content in sediment, as well as with Hou et al. (2018), who reported similar results with the sea cucumber Apostichopus japonicus.

$\mathrm{HCl}-\mathrm{P}$ is considered to be an inert and refractory form (Rydin 2000) and contributes to the long-term burial of $\mathrm{P}$ in sediments (Kaiserli et al. 2002, Jin et 
al. 2006). HCl-P is the product of OM decomposition (Yang et al. 2016, 2018). In the present study, to a large extent, the HCl-P proportions remained unchanged, especially in the bottom sediment layers, compared to the initial contents. This tendency may have been the result of $T$. granosa-induced disturbance which could only span mostly within the surface depth $(0-2 \mathrm{~cm})$ and was thus unable to influence the post-depositional transformation of Org-P, as well as the regeneration of $\mathrm{HCl}-\mathrm{P}$ under anoxic conditions (Cha et al. 2005). Similarly, the detritus of aquatic animals can influence the $\mathrm{HCl}-\mathrm{P}$ proportions in the sediments (Ruttenberg 1992, Bastami et al. 2018). Moreover, the sedimentary $\mathrm{HCl}-\mathrm{P}$ concentrations depend on the availability of calcium and manganese (Mn) in the sediment (Kaiserli et al. 2002), and from direct combination between calcite and $\mathrm{P}$, which always exists in relatively stabilized forms, e.g. $\mathrm{Ca}_{5}\left(\mathrm{PO}_{4}\right)_{3} \mathrm{OH}$, $\mathrm{Ca}_{2} \mathrm{HPO}_{4}(\mathrm{OH})_{2}$, and $\mathrm{Ca}_{3}\left(\mathrm{HCO}_{3}\right)_{3} \mathrm{PO}_{4}$ (Cassagne et al. 2000). This can further be supported by the fact that $\mathrm{HCl}-\mathrm{P}$ is not easily available to phytoplankton (Zheng et al. 2004), thus its resistance to biological influences.

$\mathrm{BD}-\mathrm{P}$ is a labile redox-sensitive $\mathrm{P}$ fraction (Zhou et al. 2001, Kaiserli et al. 2002), and an internal source for P loading (Rydin 2000). The concentration of BD$P$ in the present study was markedly affected in sediments treated with the clams, with a notable difference between the surface and middle layer (low- and high-density treatments). Küster-Heins et al. (2010) stated that BD-P bound to reducible iron and manganese $\mathrm{P}$ fractions are potentially mobile in the sediment, and can be released upon reduction of the reactive oxidized species of iron and manganese from the anoxic zone. Under anoxic conditions, occluded $\mathrm{Fe}(\mathrm{III})$ oxides are reduced to soluble $\mathrm{Fe}(\mathrm{II})$ oxides, causing the dissolution of the ferric hydroxide and promoting iron-bound phosphate ions to release from the sediment (Eukawska-Matuszewska \& Bolałek 2008). Evidence of SOC by different clams (see our Table 4) into the sediment could imply a higher supply of DO within the sediment during this study and enhanced redox conditions that favored an oxic zonation and subsequently, more P sorbed to Fe(III) (Søndergaard et al. 2003). Furthermore, in our previous studies (Nicholaus \& Zheng 2014, Zhao et al. 2019), we found that bioturbation by clams increased the oxic layer of the surface sediment. Therefore, we suggest that the adjustment of the BD-P concentration among the treatments is likely due to stimulated oxic zonation owing to the improved DO distribution by the clams. Similarly, physicochemical conditions like redox potential (Huo et al. 2011) and sediment resuspension can greatly affect various P reactions in the sediment. Khalil et al. (2007) stated that during the oxidation of OM in oxidizing sediments, a certain portion of $\mathrm{P}$ released in porewater is adsorbed on iron oxyhydroxides, carbonates, and clay minerals. Moreover, a substantial amount of $\mathrm{P}$ is retained in the sediment through adsorption to Fe oxides in the oxic surface layer (Jensen et al. 1995).

De-P is diagenetically stable, mostly derived from marine sediments and metamorphic rocks (Ruttenberg 1992, Meng et al. 2014, 2015). In the current study, De-P was among the most abundant form of $\mathrm{P}_{\text {, con- }}$ tributing about $21 \%$ of the total Inorg-P in the freshly sampled sediment, which is in agreement with previous studies (Meng et al. 2014, Song \& Liu 2015). De-P concentrations varied at the $0-2 \mathrm{~cm}$ layer $(\mathrm{p}<0.05)$, then slightly increased down the sediment depth post clam bioturbation. This probably contributed to more sediment deposition at deeper depths over the $30 \mathrm{~d}$ time period. Generally, De-P is rarely influenced by biogenic particles due to its mineralogical properties (Ruttenberg 1992) and is thus normally identified as a permanent sink of $P$ in sediment (Meng et al. 2014).

Org-P can be regarded as an inert $\mathrm{P}$ bound to hydrous iron oxides and phytoplankton ( $\mathrm{Ji}$ et al. 2009). In the present study, Org-P was strongly reduced by the clams in both treatments, suggesting the ability of clams to degrade and minimize organic effluent, which corresponds to previous findings by Zheng et al. (2011) and Nicholaus \& Zheng (2014). Further results of the present study suggest that efficient decomposition of OM occurred in the bioturbated sediments, especially in the $0-2 \mathrm{~cm}$ layer, based on a notable decrease in concentrations of OrgP. Mechanical activities by the clams, e.g. burrowing, ingestion, and digestion, can reduce the amount of accumulated OM in the sediment (Zhao et al. 2019). In addition, the transformation of Org-P to Inorg-P under enhanced microbial and alkaline phosphatase activities in the sediments can result in a decrease of Org-P fractions (Li et al. 2013, Lukwambe et al. 2018).

The commonly known bioavailable forms of $\mathrm{P}$ include Ex-P, NaOH-P, and BD-P (Kaiserli et al. 2002, Wang et al. 2019). In the current study, the bivalve clam $T$. granosa markedly increased the bioavailability level of Ex-P (61\%), NaOH (58.23\%), and BD-P $(44.44 \%)$ relative to the control, all together contributing up to $54.56 \%$ of the TP. The increase in the bioavailability of the $\mathrm{P}$ fraction in the sediment was thought to equally increase the OWP cycling rate and the total P in the overlying water. This hypothesis is supported by our previous study (Nicholaus et al. 2019) which showed a highly increased phosphate 
contents in the sediment and total $\mathrm{P}$ in the OWP in a pond bioturbated by the blood clam. In the study by Nicholaus et al. (2019), sedimentary P fluxes across the SWI increased significantly among the treated chambers, with concentrations ranging from $8.26 \pm$ $1.23 \mu \mathrm{mol} \mathrm{m}{ }^{-2} \mathrm{~h}^{-1}$ (control) to $16.02 \pm 0.65 \mu \mathrm{mol} \mathrm{m}{ }^{-2}$ $\mathrm{h}^{-1}$ (low-density treatment) and $27.97 \pm 1.09 \mu \mathrm{mol} \mathrm{m}^{-2}$ $\mathrm{h}^{-1}$ (high-density treatment). Thus, the increased bioavailability of different $P$ fraction contents as an outcome of the sediment reworking by T. granosa activities during this study can influence the TP released across the SWI. Different biological, mechanical, chemical, and environmental conditions supported by benthic macrofauna such as clams could modify the P within the sediment to be released (Zhou et al. 2001, Wu et al. 2014). The blood clam's bioturbation potential is likely to alter various conditions in the sediment such as sediment resuspension, oxygenmediated reactions, metal oxide immobilization, and OM degradation, resulting in an increased release rate. $P$ effluxes in sediments inhabited by clams have been reported (Nicholaus \& Zheng 2014, Zhao et al. 2019), thus the sediment serves as an important internal source of $\mathrm{P}$ for the overlying water.

Furthermore, a sedimental $\mathrm{P}$ species like $\mathrm{NaOH}-\mathrm{P}$ is a redox-sensitive substrate and can be released into the water under unstable redox conditions (Rydin 2000). The availability of the NaOH-P contents can be regulated through redox reaction and subsequently released from sediments across the SWI (Coelho et al. 2004). Qian et al. (2010) suggest that Org-P mineralization, HCl-P solubilization, and $\mathrm{NaOH}-\mathrm{P}$ separation are important ways in which internal $\mathrm{P}$ is released into the water column. On the other hand, microorganisms play a major role in solubilization and mineralization of $\mathrm{P}$ in the sediment. Burrow walls created by T. granosa and other clams have been found to be rich with microbes responsible for OM mineralization and effluent reduction (Pischedda et al. 2011, Lukwambe et al. 2018, Zhao et al. 2019). Further, Edlund \& Carman (2001) suggest that microorganisms play large roles in the abiding and releasing of molecules in the transient SWI, as microorganisms are capable of storing, utilizing, and releasing $\mathrm{P}$ compounds. Bioturbation activities by benthic macrofauna such as burrowing, irrigation, resuspension, feeding, excretion, and particle transportation can modify the sediment structure and properties, thereby affecting the diffusive and advective transport of both solutes and OM (Biswas et al. 2009). The positive relationship between the concentration of OWP and the TP in the sediment suggest that the amount of OWP originated from the sedi- ment and its release was probably induced by the activities of the clams.

Generally, significant concentrations of several $\mathrm{P}$ fractions mostly at the surface sediment in bioturbated sediments reflect that bioturbation probably produced a stronger effect within the surface layer (0-2 cm). Usually, T. granosa can burrow a maximum of $4 \mathrm{~cm}$ into the sediment. T. granosa is likely to exert 3 major responses in its sedimental environment that are certain to affect the cycling of P: (1) it increases the concentration of $\mathrm{O}_{2}$ in the burrows, thereby influencing the P-binding capacity of sediment, (2) it facilitates the transport of porewater $\mathrm{P}$ from sediment to water, and (3) it can move particulate oxidized compounds down to the reduced zone and reduced compounds up to the oxic zone, thus affecting ferric oxide redox in sediments.

\section{CONCLUSIONS}

The current study examined the influence of the bivalve Tegillarca granosa on the distribution and bioavailability of P fractions in an ecological aquaculture wastewater treatment system. The concentrations of BD-P, Ex-P, NaOH-P, HCl-P, and De-P exhibited an increasing trend, whereas Org-P was reduced among the clam treatments. The chambers containing the clams showed significantly higher bioavailable P (Ex-P, NaOH-P, De-P, BD-P, and HClP) fractions relative to the control. Similarly, T. granosa significantly increased the total overlying-water $\mathrm{P}$, implying that the concentration of $\mathrm{P}$ in the water column can be altered by the amounts of available $\mathrm{P}$ fractions. Our results suggest that bioturbation by clams may control the internal loading, distribution, bioavailability, and cycling of sedimental P fractions as well as Org-P reduction in benthic aquatic ecosystems, and hence may be a control measure for benthic organic effluents.

Acknowledgements. This study was supported by the Zhejiang Public Welfare Technology Research Program of China (ZPWTP) (LGN18C190008) and the K.C. Wong Magna Fund in Ningbo University.

\section{LITERATURE CITED}

Andrieux-Loyer F, Aminot A (2001) Phosphorus forms related to sediment grain size and geochemical characteristics in French coastal areas. Estuar Coast Shelf Sci 52: 617-629

Bastami KD, Neyestani MR, Raeisi H, Shafeian E and others (2018) Bioavailability and geochemical speciation of 
phosphorus in surface sediments of the Southern Caspian Sea. Mar Pollut Bull 126:51-57

Biswas JK, Rana S, Bhakta JN, Jana BB (2009) Bioturbation potential of chironomid larvae for the sediment-water phosphorus exchange in simulated pond systems of varied nutrient enrichment. Ecol Eng 35:1444-1453

Bostic EM, White JR (2007) Soil phosphorus and vegetation influence on wetland phosphorus release after simulated drought. Soil Sci Soc Am J 71:238-244

Cao X, Zhu J, Lu M, Ge C, Zhou L, Yang G (2019) Phosphorus sorption behavior on sediments in Sanggou Bay related with their compositions by sequential fractionation. Ecotoxicol Environ Saf 169:144-149

* Cassagne N, Remaury M, Gauquelin T, Fabre A (2000) Forms and profile distribution of soil phosphorus in alpine Inceptisols and Spodosols (Pyrenees, France). Geoderma 95:161-172

* Cha HJ, Lee CB, Kim BS, Choi MS, Ruttenberg KC (2005) Early diagenetic redistribution and burial of phosphorus in the sediments of the southwestern East Sea (Japan Sea). Mar Geol 216:127-143

* Chen J, Lu S, Zhao Y, Wang W, Huang M (2011) Effects of overlying water aeration on phosphorus fractions and alkaline phosphatase activity in surface sediment. J Environ Sci (China) 23:206-211

Coelho JP, Flindt MR, Jensen HS, Lillebø AI, Pardal MA (2004) Phosphorus speciation and availability in intertidal sediments of a temperate estuary: relation to eutrophication and annual P-fluxes. Estuar Coast Shelf Sci 61:583-590

Crab R, Avnimelech Y, Defoirdt T, Bossier P, Verstraete W (2007) Nitrogen removal techniques in aquaculture for sustainable production. Aquaculture 270:1-14

Cubillo AM, Ferreira JG, Robinson SMC, Pearce CM, Corner RA, Johansen J (2016) Role of deposit feeders in integrated multi-trophic aquaculture-a model analysis. Aquaculture 453:54-66

Edlund G, Carman R (2001) Distribution and diagenesis of organic and inorganic phosphorus in sediments of the Baltic proper. Chemosphere 45:1053-1061

FAO (2016) Food and agriculture - key to achieving the 2030 agenda for sustainable development. FAO, Rome. www.fao.org/3/a-i5499e.pdf

Hall SJ, Delaporte A, Phillips MJ, Beveridge M, O'Keefe M (2011) Blue frontiers: managing the environmental costs of aquaculture. WorldFish, Penang

* Hou YR, Sun YJ, Gao QF, Dong SL, Wen B, Pan Z, Liu C (2018) Bioturbation by sea cucumbers Apostichopus japonicus affects sediment phosphorus forms and sorption characteristics. Aquacult Environ Interact 10:201-211

*Huo S, Zan F, Xi B, Li Q, Zhang J (2011) Phosphorus fractionation in different trophic sediments of lakes from different regions, China. J Environ Monit 13:1088-1095

Jensen HS, Mortensen PB, Andersen FØ, Rasmussen EK, Jensen A (1995) Phosphorus cycling in coastal marine sediment. Limnol Oceanogr 40:908-917

Ji FY, Cao L, Lin M, Wang TJ, Li S (2009) Phosphorus forms analysis in sediments of the newly emerged fluctuation zone in Three Gorges Reservoir area. Res Environ Sci 8: 882-886 (in Chinese)

* Jin X, Wang S, Pang Y, Change WF (2006) Phosphorus fractions and the effect of $\mathrm{pH}$ on the phosphorus release of the sediments from different trophic areas in Taihu Lake, China. Environ Pollut 139:288-295

Kaiser K, Eusterhues K, Rumpel C, Guggenberger G, KögelKnabner I (2002) Stabilization of organic matter by soil minerals - investigations of density and particle-size fractions from two acid forest soils. J Plant Nutr Soil Sci 165:451-459

Kaiserli A, Voutsa D, Samara C (2002) Phosphorus fractionation in lake sediments-Lakes Volvi and Koronia, N. Greece. Chemosphere 46:1147-1155

Karlson K, Hulth S, Ringdahl K, Rosenberg R (2005) Experimental recolonization of Baltic Sea reduced sediments: survival of benthic macrofauna and effects on nutrient cycling. Mar Ecol Prog Ser 294:35-49

Khalil MK, Radwan AM, El-Moselhy KM (2007) Distribution of phosphorus fractions and some of heavy metals in surface sediments of Burullus Lagoon and adjacent Mediterranean Sea. Egypt J Aquat Res 33:277-289

Kuang SJ, Sun H (1995) Preliminary study on suitable environmental conditions for embryonic and larval development of blood clam Tegillarca granosa. In: Annual Report (1995) of National Climb B Plan 'Fundamental Studies on Improving the Germplasm and Disease Resistance of Mariculture Species', p 127-134

Küster-Heins K, Steinmetz E, De Lange GJ, Zabel M (2010) Phosphorus cycling in marine sediments from the continental slope off Namibia. Mar Geol 274:95-106

Li H, Liu L, Li M, Zhang X (2013) Effects of $\mathrm{pH}$, temperature, dissolved oxygen, and flow rate on phosphorus release processes at the sediment and water interface in storm sewer. J Anal Methods Chem 2013:104316

Li Z, Tang H, Xiao Y, Zhao H, Li Q, Ji F (2016) Factors influencing phosphorus adsorption onto sediment in a dynamic environment. J Hydro-Environ Res 10:1-11

* Lin P, Guo L, Chen M, Cai Y (2013) Distribution, partitioning and mixing behavior of phosphorus species in the Jiulong River estuary. Mar Chem 157:93-105

Łukawska-Matuszewska K, Bolałek J (2008) Spatial distribution of phosphorus forms in sediments in the Gulf of Gdansk (southern Baltic Sea). Cont Shelf Res 28:977-990

Lukwambe B, Yang W, Zheng Y, Nicholaus R, Zhu J, Zheng Z (2018) Bioturbation by the razor clam (Sinonovacula constricta) on the microbial community and enzymatic activities in the sediment of an ecological aquaculture wastewater treatment system. Sci Total Environ 643: 1098-1107

Mao Y, Lin F, Fang J, Fang J, Li J, Du M (2019) Bivalve production in China. In: Smaal AC, Ferreira J, Grant J, Petersen J, Strand $\varnothing$ (eds) Goods and services of marine bivalves. Springer, Cham, p 51-72

*Masuda K, Boyd CE (1994) Phosphorus fractions in soil and water of aquaculture ponds built on clayey Ultisols at Auburn, Alabama. J World Aquacult Soc 25:379-395

* Meng J, Yao P, Yu Z, Bianchi TS, Zhao B, Pan H, Li D (2014) Speciation, bioavailability and preservation of phosphorus in surface sediments of the Changjiang Estuary and adjacent East China Sea inner shelf. Estuar Coast Shelf Sci 144:27-38

* Meng J, Yu Z, Yao Q, Bianchi TS and others (2015) Distribution, mixing behavior, and transformation of dissolved inorganic phosphorus and suspended particulate phosphorus along a salinity gradient in the Changjiang Estuary. Mar Chem 168:124-134

Newell RIE (2004) Ecosystem influences of natural and cultivate populations of suspension-feeding bivalve mollusks: a review. J Shellfish Res 23:51-61

* Nguyen TT, Choi YJ, Rohmah Z, Jeong SB, Hwang DJ, Jung YG, Choi BD (2017) Seasonal variations of nutritional components in cockles (Tegillarca granosa) processed 
from the southern coast of Korea. Cogent Food Agric 3: 1360102

Nicholaus R, Zheng Z (2014) The effects of bioturbation by the Venus clam Cyclina sinensis on the fluxes of nutrients across the sediment-water interface in aquaculture ponds. Aquacult Int 22:913-924

Nicholaus R, Lukwambe B, Zhao L, Yang W, Zhu J, Zheng Z (2019) Bioturbation of blood clam Tegillarca granosa on benthic nutrient fluxes and microbial community in an aquaculture wastewater treatment system. Int Biodeterior Biodegradation 142:73-82

Phuc TH (1997) Biological characters and technique of oyster Anadara granosa culture at Tra Vinh coastal water. Fish Rev 1997:6

Pischedda L, Poggiale JC, Cuny P, Gilbert F (2011) Oxygen distribution heterogeneity related to bioturbation quantified by planar optode imaging. In: Ceccaldi HJ, Dekeyser I, Girault M, Stora G (eds) Global change: mankindmarine environment interactions. Springer, Dordrecht, p 277-282

Qian Y, Shi J, Chen Y, Lou L and others (2010) Characterization of phosphate solubilizing bacteria in sediments from a shallow eutrophic lake and a wetland: isolation, molecular identification and phosphorus release ability determination. Molecules 15:8518-8533

Ramli MFS, Abu Hasan FR (2013) Feeding cockles (Anadara granosa) with detritus balls. IISTE J Biol Agric Healthc 3: 102-107

Reddy KR, Wetzel RG, Kadlec RH (2005) Biogeochemistry of phosphorus in wetlands. Agron Monogr 46:263-316

Ribeiro DC, Martins G, Noguera R, Cruz JV, Brito AG (2008) Phosphorus fractionation in volcanic lake sediments (Azores-Portugal). Chemosphere 70:1256-1263

Roy-Poirier A, Champagne P, Filion Y (2010) Bioretention processes for phosphorus pollution control. Environ Rev 18:159-173

Ruttenberg KC (1992) Development of a sequential extraction method for different forms of phosphorus in marine sediments. Limnol Oceanogr 37:1460-1482

Rydin E (2000) Potentially mobile phosphorus in Lake Erken sediment. Water Res 34:2037-2042

* Shilla DA, Asaeda T, Kalibbala M (2009) Phosphorus speciation in Myall Lake sediment, NSW, Australia. Wetlands Ecol Manage 17:85-91

Slomp CP, Epping EHG, Helder W, Raaphorst WV (1996) A key role for iron-bound phosphorus in authigenic apatite formation in North Atlantic continental platform sediments. J Mar Res 54:1179-1205

Søndergaard M, Jensen JP, Jeppesen E (2003) Role of sediment and internal loading of phosphorus in shallow lakes. Hydrobiologia 506:135-145

Song G, Liu S (2015) Phosphorus speciation and distribution in surface sediments of the Yellow Sea and East China Sea and potential impacts on ecosystem. Acta Oceanol Sin 34:84-91

* Wang S, Jin X, Pang Y, Zhao H, Zhou X, Wu F (2005) Phosphorus fractions and phosphate sorption characteristics in relation to the sediment compositions of the shallow lakes in the middle and lower reaches of Yangtze River. J Colloid Interface Sci 289:339-346

* Wang S, Jin X, Bu Q, Zhou X, Wu F (2006) Effects of particle size, organic matter and ionic strength on the phosphate sorption in different trophic lake sediments. J Hazard Mater 128: 95-105
Wang ZH, Feng J, Nie XP (2015) Recent environmental changes reflected by metals and biogenic elements in sediments from the Guishan Island the Pearl River Estuary, China. Estuar Coast Shelf Sci 164:493-505

*Wang T, Liu J, Xu S, Qin G, Sun Y, Wang F (2017) Spatial distribution, adsorption/release characteristics, and environment influence of phosphorus on sediment in reservoir. Water 9:724

*Wang Y, Li K, Liang R, Han S, Li Y (2019) Distribution and release characteristics of phosphorus in a reservoir in southwest China. Int J Environ Res Public Health 16:303

*White JR, Reddy KR (1999) Influence of nitrate and phosphorous loading on denitrification enzyme activity in everglades wetland soil. Soil Sci Soc Am J 63: 1945-1954

WWu Y, Wen Y, Zhou J, Wu Y (2014) Phosphorus release from lake sediments: effects of $\mathrm{pH}$, temperature and dissolved oxygen. KSCE J Civ Eng 18:323-329

*Yang B, Liu SM, Wu Y, Zhang J (2016) Phosphorus speciation and availability in sediments off the eastern coast of Hainan Island, South China Sea. Cont Shelf Res 118: 111-127

Y Yang B, Liu SM, Zhang GL (2018) Geochemical characteristics of phosphorus in surface sediments from the continental shelf region of the northern South China Sea. Mar Chem 198:44-55

* Yang B, Zhou JB, Lu DL, Dan SF and others (2019) Phosphorus chemical speciation and seasonal variations in surface sediments of the Maowei Sea, northern Beibu Gulf. Mar Pollut Bull 141:61-69

Zak D, Gelbrecht J (2002) Phosphorus retention at the redox interface of peatlands adjacent to surface waters. Wasser Boden 54:71-76

Z Zhang R, Wu F, Liu C, Fu P and others (2008) Characteristics of organic phosphorus fractions in different trophic sediments of lakes from the middle and lower reaches of Yangtze River region and Southwestern Plateau, China. Environ Pollut 152:366-372

* Zhang L, Gu X, Fan C, Shang J, Shen Q, Wang Z, Shen J (2010) Impact of different benthic animals on phosphorus dynamics across the sediment-water interface. J Environ Sci (China) 22:1674-1682

* Zhang L, Shen Q, Hu H, Shao S, Fan C (2011) Impacts of Corbicula fluminea on oxygen uptake and nutrient fluxes across the sediment-water interface. Water Air Soil Pollut 220:399-411

Zhao L, Zheng Y, Nicholaus R, Lukwambe B, Zhu J, Yang W, Zheng Z (2019) Bioturbation by the razor clam Sinonovacula constricta affects benthic nutrient fluxes in aquaculture wastewater treatment ecosystems. Aquacult Environ Interact 11:87-96

* Zheng L, Ye Y, Zhou H (2004) Phosphorus forms in sediments of the East China Sea and its environmental significance. J Geogr Sci 14:113-120

* Zheng Z, Lv J, Lu K, Jin C, Zhu J, Liu X (2011) The impact of snail (Bellamya aeruginosa) bioturbation on sediment characteristics and organic carbon fluxes in a eutrophic pond. Clean Soil Air Water 39:566-571

Z Zhou Q, Gibson CE, Zhu Y (2001) Evaluation of phosphorus bioavailability in sediments of three contrasting lakes in China and the UK. Chemosphere 42:221-225

Zhu G, Wang F, Gao G, Zhang Y (2008) Variability of phosphorus concentration in large, shallow and eutrophic Lake Taihu, China. Water Environ Res 80:832-839 